\section{SOME SEVENTEENTH-CENTURY MINIATURES FROM THE UNIVERSITY OF CRACOW}

\section{$\mathrm{T}$} The part played by the universities of Central Europe in the development of emblematic and allegorical illustration has not yet been fully investigated, but a cursory glance at the material which has been preserved is sufficient to indicate that in the universities, a distinctive type, different from that of the court, church or bourgeois milieus, had already made its appearance by the sixteenth century. ${ }^{1}$ Among the more interesting records of academic imagery of this kind are the libri promotionum and libri diligentiarum of the Jagellonian University of Cracow, ${ }^{2}$ which contain the records of promotions, lectures and disputations in the Faculty of Arts and are decorated, between the end of the sixteenth and the beginning of the eighteenth century, by amateur painters from among the graduates and students of the faculty. These miniatures are interesting, despite their very moderate artistic value, in that they reveal how certain allegorical motives were transformed within the context of a seventeenthcentury university.

These allegories are usually panegyric in tendency, and their imagery is often drawn from mathematics and astronomy, for which the Jagellonian University was already famous in the late Middle Ages and Renais-

${ }^{1}$ Attention has been drawn to the need for the study of this problem by S. Stelling-Michaud, 'L'Histoire des universités au Moyen Age et la Renaissance au cours des 25 dernières années', Extrait des rapports du IIme Congrès international des sciences historiques, Stockholm, I96o, p. I29. See also P. Ganz, Die Miniaturen der Baseler Universitätsmatrikel, 1960.

${ }^{2}$ Cracow, Jagellonian Library, Department of MSS : Libri Diligentiarum, MSS. 232, 220; Liber Promotionum, MS. 252; University Archives: Libri Diligentiarum, MS. 90, 91 ; Liber Promotionum, MS. 91 1/2. sance. Moreover, from the sixteenth century onwards, Cracow possessed a highly developed tradition of purely scientific illustration. ${ }^{3}$ The use of scientific subject-matter for allegorical and panegyric, rather than purely scientific purposes - a tendency which first appears in the libri of the University about the end of the seventeenth century-marks a change in attitude: scientific imagery is being used, in an academic context, for non-scientific, rhetorical purposes. Initially, this scientific imagery is merely a kind of addition to a conventional panegyric of a graduand, but, with the course of time, it becomes the dominant feature, on which the panegyric turns, and by the eighteenth century it tends to outweigh the literary aspect altogether.

The process may be illustrated with a few examples, of which the first (Pl. 5ra) dates from 1688 and interweaves an astronomical and a mythological theme. It represents Atlas, bearing a disproportionately large cosmos, constructed on two planes: the lower half of the globe has the shape of an armillary sphere, while the upper is the cosmos seen in section, showing the arrangement of the spheres with the earth in its centre. Both armillary sphere and section of the cosmos belong to the standard equipment of illustrated astronomical handbooks of the sixteenth century. ${ }^{4}$

The spheres are inscribed with the names of the graduates, who were eleven in all, and this has caused the illustrator to depart from the strict canons of astronomy to satisfy the requirements of panegyric and give each name a sphere of its own. The seven gifts of

${ }^{3}$ See C. Nissen, Die naturwissenschaftliche Illustration. Ein geschichtlicher Uberblick, I950, pp. 33-43.

4 E. Chojecka, 'Krakowska grafika kalendarzowa i astronomiczna XVI w., Studia Renesansowe, iii, I963, pp. 425-43, figs. I24-3I, I $34-43$. 
the Holy Ghost are shown above, with the inscription Habent docti fideles sacrum septenarium, while the central notion of the miniature, the elevation of the doctorandi to immortal glory among the planets, is emphasized by the inscriptions Comportat doctos Athlas ad pondera laudis, and Coniungens dignos sphaerica iuncta refert. The idea of the hero's being carried to immortal glory among the stars is to be found, of course, in ancient Greek thought, but the direct literary source of our picture of Atlas is to be found in contemporary Cracovian university panegyric, which is full of titles and expressions such as Splendor laureati sideris ${ }^{5}$ and Universitas Cracoviensis suis gradibus, tanquam sphaeris, seu caelestibus, seu elementaribus, distincta ${ }^{6}$ equating university and cosmos, graduands and stars. The appearance of Atlas bears no resemblance to his classical representations, which may be the result of the neglect of painting, sculpture and architecture in the university curriculum of the time. We have here the paradox of finished classical verbal panegyric, accompanying an illustration relatively crude in conception, as well as in execution.

An earlier miniature (Pl. $5 \mathrm{Ib}$ ), of ${ }_{1} 678$, the year of a great epidemic, is another transformation of Atlas, and demonstrates once again the great flexibility of both the mythological and the scientific imagery used in the miniatures. The sphere is borne not by Atlas, but by Death, the manifestation of Ira Dei (symbolized by the eagle above), whose power over all men is indicated by the tools and instruments of the various trades and occupations, which decorate the sphere he carries. Perhaps a reminiscence of the traditional imagery of the Dance of Death and the 'Feiertags-Christus' may be discerned here. ' At any rate, the intention is clear: God's wrath, in the form of the plague, has visited Cracow, and carried off so many men of all conditions that there have been no candidates for promotion in that year.

But about I 700, scientific imagery seems to gain ground, and sometimes dominates

\footnotetext{
${ }^{5}$ M. Ośliński, Splendor laureati sideris . . . Cracow, 1685 .

${ }^{6}$ R. K. Arteński, Unio theologicus ...., Cracow, I68I, fol. $\mathrm{B}^{2}$.

7 The danse macabre was a popular subject in Polish painting in the seventeenth century. On the 'Feiertagschristus' or 'Christ of the Trades' see R. Wildhaber, "Der "Feiertagschristus" als ikonographischer Ausdruck der Sonntagsheiligung,, Zeitschrift für Schweizerische Archäologie und Kunstgeschichte, xvi, 1956, pp. I-34.
}

and determines the miniature's compositional scheme, as in a miniature of r699 (Pl. 5Ic). This shows the plan of a pentagonal citadel of Italian type, as we know it from sixteenthcentury textbooks on fortification, within which are depicted three colleges. The triangular spaces of the bastions bear the names of the five graduands, to whom the invocation Almae Praesidum este parentis, nocte dieque also refers. The motto at the top Deus impare numero gaudet $^{8}$ no doubt refers to the Pythagorean idea of the superiority of odd numbers, ${ }^{9}$ with a side allusion to the number of the graduands. The pentagonal shape may be an allusion to the pentagram, the magical figure of defence, ${ }^{10}$ in this case linked with the picture of the fortress. ${ }^{11}$

The tendency to allegorize scientific themes, luxuriantly developed in the seventeenth century, becomes distinctly weaker in the eighteenth. A drawing of I72I (Pl. 5Id), depicting an eclipse of the moon, similar to the sort of picture found in scientific treatises, may serve as an example of this. Though the draughtsman could not quite stop himself from turning the illustration of an eclipse into a device by adding the words Quantum distat $a b$ illo, and though he retained the old anthropomorphic figure of the solar disc, the illustration does mark the opening of a new phase, the result of the new outlook on science, more objective and matter-of-fact, the beginning of the Enlightenment. Soon after this, the habit of decorating the records of promotions and lectures died out in Cracow, and scientific illustration shrinks back into the textbooks and treatises which were its first home and where it merely serves to elucidate the text, without attempting any decorative or moralizing functions.

If we consider the theoretical foundations of our miniatures, we may feel that they depend on Renaissance notions of the unity

\footnotetext{
${ }^{8}$ Vergil, Buc. viii. 75 .

${ }^{9}$ See V. F. Hopper, Medieval Number Symbolism . . ., I 938 , p. 40.

${ }_{10}$ On the magical meaning of the pentagram see F. J. Dölger, 'Der Stempel mit Pentagram, $\Theta$ und YTIEIA im Historischen Museum zu Basel der Stempel eines antiken Arztes', Antike und Christentum ...., i, r929, pp. $5^{\mathrm{I}-53}$; and Agrippa of Nettesheim, Opera, ii, Lyons, c. I650, pp. 32 I, 491 .

${ }^{11}$ In spite of its highly theoretical character, the academic 'Pythagorean fortress' apparently expresses the sentiment of the university community in a concrete situation: the acute feeling of isolation and of the enmity of the surrounding world. This is hardly accidental, when we consider the severe conflicts with the Jesuits and the social isolation which the University suffered in the seventeenth century.
} 
of the liberal arts. ${ }^{12}$ But in them the literary and scientific imagery are stronger than the provincial and amateur artistic expression. So far from fulfilling the requirements of Renais-

12 E. Panofsky, Renaissance and Renaissances in Western Art, 1960, pp. 15-16. J. R. Spencer, "Ut Rhetorica Pictura". A Study in Quattrocento Theory of Painting', this Journal, XX, I957, pp. 26-44. sance theorists, they present an antinomy between the complex and serious theme, and the simplicity and naïveté of the pictorial expression. Moreover, the panegyric purpose of the miniatures did not permit the introduction of the only factor which might have alleviated this disharmony - $a$ touch of humour.

Ewa Chojecka 